University of Chicago Law School

Chicago Unbound

Journal Articles

Faculty Scholarship

1942

\title{
Misrepresentation and False Warranty in the Illinois Insurance Code
}

Friedrich Kessler

Albert Armin Ehrenzweig

Follow this and additional works at: https://chicagounbound.uchicago.edu/journal_articles

Part of the Law Commons

\section{Recommended Citation}

Friedrich Kessler \& Albert Armin Ehrenzweig Sr., "Misrepresentation and False Warranty in the Illinois Insurance Code," 9 University of Chicago Law Review 209 (1942).

This Article is brought to you for free and open access by the Faculty Scholarship at Chicago Unbound. It has been accepted for inclusion in Journal Articles by an authorized administrator of Chicago Unbound. For more information, please contact unbound@law.uchicago.edu. 


\title{
UNIVERSITY OF CHICAGO LAW REVIEW \\ VOLUME 9 \\ FEBRUARY 1942 \\ NUMBER 2
}

\section{MISREPRESENTATION AND FALSE WARRANTY IN THE ILLINOIS INSURANCE CODE}

\author{
ALbert Ehrenzweig, SR.,* aNd Friedrich Kessler $\dagger$
}

I

O TATUTORY provisions dealing with misrepresentations and false warranties did not exist in Tllinois prior to the enactment of Section 154 of the Illinois Insurance Code of $1937 .{ }^{x}$ A considerable number of other states had, in recent years, already adopted similar legislation, some of which, however, was limited to health and accident insurance, to life insurance, or to group life insurance. ${ }^{2}$ The Illinois legislature enacted a statute covering all types of insurance ${ }^{3}$ - a desirable deviation. The need for protecting the insured in this matter is not confined to the field of insurance of the person. ${ }^{4}$ Section 154 reads as follows:

No misrepresentation or false warranty made by the insured or in his behalf in the negotiation for a policy of insurance, or breach of a condition of such policy shall defeat or avoid the policy or prevent its attaching unless such misrepresentation, false

* Research Associate and Lecturer in the Law of Insurance, Northwestern University; formerly Professor of Law, University of Vienna, and Insurance Commissioner of Austria.

$\dagger$ Associate Professor of Law, University of Chicago.

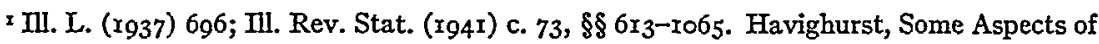
the Illinois Insurance Code, 32 Ill. L. Rev. 39I (1937); see also Goble, Codification of Illinois Insurance Laws, 3o Ill. L. Rev. 695 (I936).

${ }^{2}$ A list of those statutes is to be found in Illinois Insurance Code Annotated 284 (Annotating Committee of the Section on Insurance Law of the Illinois State Bar Association, I939) and in Statutes Affecting Representations in Insurance Contracts, 32 Col. L. Rev. 522 (1932).

3 Only marine and transportation insurance are excepted. These branches still present quite different problems of insurance law policy.

4 It is true that insurance of the person, particularly life insurance, makes a delicate and cautious treatment necessary, since the object of the insurance contract is a human being and quite frequently the applicant himself. It is obvious that in the field of insurance of the person the statements relating to the risk have a different meaning to the applicant than in the field 
warranty or condition shall have been stated in the policy or endorsement or rider attached thereto, or in the written application therefor, of which a copy is attached to or endorsed on the policy, and made a part thereof. No such misrepresentation or false warranty shall defeat or avoid the policy unless it shall have been made with actual intent to deceive or materially affects either the acceptance of the risk or the hazard assumed by the company. This section shall not apply to policies of marine or transportation insurance.

This provision represents a new phase in the evolution of the Illinois law of warranties and representations in insurance contracts. The Illinois common law in the matter has frequently been called confusing, but this harsh criticism is not altogether deserved. While it is true that the Illinois decisions do not fit easily into a clear pattern and that some can hardly be reconciled on a theoretical level, this "confusion" was an inevitable accompaniment of the efforts of the Illinois courts to break away from outdated concepts and rules the wisdom of which had become increasingly problematical.

With all their confusion, the Hlinois decisions represent a healthy reaction against the classical warranty rule as it was developed by Lord Mansfield and defended by Baron Parke's rhetoric for the law of marine insurance. ${ }^{5}$ Disliking the uncritical extension of the warranty doctrine to non-marine risks, an extension of which prior generations of lawyers had been guilty, the Illinois courts frequently paid but empty honor to the doctrine's memory. They have been loath to construe statements of the insured as warranties "unless the provisions of the application and the policy taken together have left no room for any other construction." 6 To protect the insured against the doctrine that a warranty as contrasted to a representation must be literally true to create a liability, courts have shown a tendency to label statements of the insured as representations rather than warranties whenever possible so that a wrong description of the risk by the insured would be fatal only if it materially affected the

of property insurance. Psychological impediments have to be taken into consideration. Quite frequently false statements are caused by self-deception as a result of the will to live, a psychological factor which has been taken into account frequently by saying that statements as to health are merely statements of opinion. Patterson, Essentials of Insurance Law 343 et seq. (I935). But all these peculiarities of life insurance can be taken care of through the judicial process if the statutory provisions are flexible enough.

5 De Hahn v. Hartley, I Term Rep. 343 (K.B. r786); Park, Insurance 3 I8 (3d ed. I796); Vance, The Fistory of the Development of the Warranty in Insurance Law, 20 Yale L. J. 523 (I9II); Patterson, Warranties in Insurance Law, 34 Col. L. Rev. 595 (1934).

${ }^{6}$ McClary v. Grand Lodge Brotherhood, 282 Ill. App. 77 (I935); The Illinois Insurance Code Annotated 287 (1939). 
risk. ${ }^{7}$ This has been done by the courts even with respect to statements in the application which the insurer had tried to raise to the dignity of warranties by incorporating the application into the policy. ${ }^{8}$ To lend respectability to their efforts, courts have often resorted to a fiction and have claimed to be carrying out the "intention" of the parties," even holding that use of the word "warranty" is not conclusive..$^{\text {xo }}$ Some seem to have gone so far as in effect to apply the test: could the applicant reasonably be held to have absolute knowledge as to the facts stated, and could the parties reasonably be held to have intended that the applicant should virtually guarantee the truth of his statements? ${ }^{\text {Ix }}$

By breaking down the clear line of demarcation between warranties and representations traditionally observed by the common law courts for more than a century, ${ }^{12}$ these courts frustrated the ill-advised efforts of insurance companies to turn all statements of the insured into warranties. Yet the courts did not feel free to emancipate themselves completely from the common law's prejudicial attitude and to abandon the warranty concept altogether, and sometimes they have become entangled in the drapery of words or have been frightened by their own daring. Such an attitude is not surprising in a legal system like that of the common law, whose concepts and theories show a particular vitality and longevity due to the strength of "group persistences." " The progress of the common law was rather slow and uneven and too often its inconsistencies became painfully apparent. Consequently, a new effort was felt necessary to bring about a rational and more radical solution of the law of warranties and representations. Section I54 was the result. The question now is whether the effort has been successful.

' Spence v. Central Accident Ins. Co., 236 IIl. 444, 86 N.E. I04 (Ig08).

${ }^{8}$ Minnesota Mutual Life Ins. Co. v. Link, 230 Ill. 273, 82 N.E. 637 (xg०7).

9 Tbid., citing Moulor v. American Life Ins. Co., IIr U.S. 335 (1884).

20 Provident Savings Life Assurance Society v. Cannon, I03 Ill. App. 534, 546 (1902), aff'd 201 IIl. 260,66 N.E. 388 (I903). Contra: McClary v. Grand Lodge Brotherhood, $282 \mathrm{IIl}$. App. 77 (r935); Crosse v. Supreme Lodge, 254 IIl. 80, 98 N.E. 26I (I9r2).

Ir Bailey v. Fraternal Reserve Life Ass'n, 202 IIl. App. 430 (Igr6); Globe Mutual Life Ins. Ass'n v. Wagner, I88 Ill. I33, 58 N.E. 970 (I900); Minnesota Mutual Life Ins. Co. v. Link, 230 III. 273,82 N.E. 637 (I907); 25 Iowa L. Rev. 38I (I940), noting Smith v. Monumental Life Ins. Co., 30r Ill. App. 217, 22 N.E. (2d) 399 (1939).

I2 Kenyon v. Berthon (N.P. I779), reported in Park, Insurance 426 (6th ed. I809); Sohn v. New York Indemnity Co., 340 IIl. I29, 172 N.E. 54 (1930); Spence v. Central Accident Ins. Co., 236 Ml. 444, 86 N.E. I04 (I908), noted in 7 Mich. L. Rev. 438 (Igo9); Misstatements Which Avoid Insurance Policies, 7 I U. of Pa. L. Rev. I4I (I922); Vance, op. cit. supra note 5, at $527,531,534$.

${ }_{3} 2$ Pareto, The Mind and Society $\$ \$ 842$ et seq. (r935). 
According to the commentary of the Annotating Committee, the meaning of Section $x_{54}$ is quite clear: it "places representations and warranties upon the same footing. It has restricted the rules heretofore applied to warranties and broadened those applied to representations." The commentary also suggests that the common law distinction between representations and warranties, "heretofore observed by Illinois courts to a large extent," has been abolished. ${ }^{14}$

This interpretation seems quite persuasive. The first sentence of Section $r_{54}$ does indeed put representations and warranties (and conditions) on the same footing by requiring as'a prerequisite of their binding effect the same form of documentation. ${ }^{.5}$ According to the second sentence of the section, a misrepresentation or false warranty does not defeat the policy unless it has "been made with actual intent to deceive or materially affects either the acceptance of the risk or the hazard assumed by the company." An immaterial breach of a warranty, if there is no intent to deceive, is therefore no longer fatal, and to this extent warranties and representations have also been put on the same footing.

But these observations do not exhaust all the implications of Section I54 as it is understood by the Annotating Committee, and these must be articulated clearly in order to determine whether Section $\mathrm{I}_{54}$ as interpreted by the Annotating Committee has brought about a successful solution of the problem presented by warranties and representations. Although the Annotating Committee's commentary does not say so expressly, the presence of either fraud or materiality under the committee's theory is not only necessary but also sufficient to defeat recovery. The consequences of this theory are considerable.

${ }_{44}$ The Illinois Insurance Code Annotated 285 (1939).

is In this respect the statute amounts to a considerable improvement upon the common law which recognized the binding force of representations that were not made part of the policy. Sohn v. New York Indemnity Co., 340 Ill. I29, I72 N.E. 52 (I930). Since under the second sentence of Section 154 misrepresentations may have the same fatal consequences as have false warranties, there are indeed strong reasons for prescribing the same formal requisites for both.

The meaning of the term "condition" has not been elucidated by Tllinois decisions. Some courts have used warranty and condition as synonymous terms. A comparison of the first sentence which mentions conditions with the second sentence which omits to mention them makes it clear $r_{2}$ however, that "condition" in terms of $\$ 154$ means conditions which do not relate to the risk as warranties do. Under this interpretation it makes good sense that only the first sentence of $\S_{54}$ mentions conditions. It is a good thing to be quite explicit in extending the requirement of documentation to all conditions to eliminate the possibility of an argumemtum e contrario. The fraud or increase-of-hazard test, on the other hand, provided for in the second sentence, is properly applied only to conditions relating to the risk, i.e., warranties, and not to other conditions of the insurer's liability, as, for instance, the very important condition, "payment of the first premium." 
Since the statute does not define "material," it must be assumed that this term of art has the meaning given it by the common law literature and particularly by case law. According to the common law, a misrepresentation (or false warranty) is material if the "true facts increase substantially the chances of the event insured against so as to cause a rejection of the application or the imposition of different conditions." 16 Since "different conditions" include higher premiums, ${ }^{17}$ Mlinois courts accepting the Annotating Committee's version of Section I54 would have to regard a false description of the risk as fatal, not only if the true description of the risk would have resulted in a rejection of the application, but also if it would have caused only a slight increase of premiums. And they would be unable to differentiate in this respect between false warranties and misrepresentations, since the distinction is said to be abolished. The resulting rigidity of the law would represent a deplorable step backwards when contrasted with the flexibility of the preexisting Illinois common law. Heretofore in actions at law many Illinois decisions have held that false representations are fatal only if the insured "had failed to communicate .... what he knew or should have known was material to the risk." Ix8 It is true that the potentialities of loosening up "hardened" concepts lying in these decisions have never been fully used, but they can hardly be overestimated, particularly if we remind ourselves of the tendency of the Illinois courts to turn warranties into representations whenever possible.

But the sorry plight of the insured might not end here. Under the act a misrepresentation or breach of warranty is fatal if it "materially affects either the acceptance of the risk or the hazard assumed by the company." It could be contended by the insurance companies, and they certainly will make the most of it, that the statute by stating these alternatives intended to substitute the individual insurer standard for a purely objective test. ${ }^{9}$ This interpretation could be fortified by contrasting the Illinois

${ }^{16}$ Penn Mutual Life Ins. Co. v. Mechanics' Savings Bank \& Trust Co., $7^{2}$ Fed. 413, $4^{23}$ (C.C.A. 6th I896); Hancock v. Nat'l Council of the Knights and Ladies of Security, $303 \mathrm{III}$. 66, 135 N.E. 33 (1922); Wasem v. Metropolitan Life Ins. Co., 269 Ill. App. 275 (I933); as to the possible tests of materiality see $\mathrm{New}$ York Insurance Code of I939, $40 \mathrm{Col}$. L. Rev. 880, 887 (I940).

${ }^{17}$ New York Insurance Code of $x 939,40$ Col. L. Rev. 880, 887 (1940).

${ }^{18}$ Moulor v. American Life Ins. Co., III U.S. 335, 346 (1884), constantly cited by tllinois cases; see Thompson v. State Mutual Life Assurance Co., 305 Ml. App. 255, 27 N.E. (2d) 330 (1940). These decisions tend toward a culpability principle, page 222 infra.

${ }^{19}$ The dangers of the subjective standard for the insured are well illustrated by a New York decision dealing with a case where the two alternatives were provided for in the insurance policy. A juror had asked the court, "Suppose we believe the company when it said it would not insure the plaintiff if the company knew the defect, but do not believe they would 
statute with those statutes of sister states which have only the materialto-the-risk alternative. ${ }^{20}$ Such a reading of the subjective insurer test into the statute also means a worsening of the position of the insured. Heretofore many Illinois courts when applying the materiality test to misrepresentations have afforded the insured protection by determining materiality from the point of view of a reasonably careful and intelligent man. ${ }^{2 x}$

In view of these important implications of the statutory interpretation presented by the Annotating Committee, a careful examination of the statute's wording is necessary. Is it true that according to the statute the presence of either fraud or materiality is not only required but also sufficient? A careful reading of the statute reveals, as Havighurst has already observed, that "the provision is phrased so as to state what will not defeat the policy, not what will defeat it. Insofar as there is an indication that one of the facts will defeat the policy it rests wholly on implication.."22 In other words, Section 154 does not expressly say that fraud, unacceptability of the risk, and underinsurance due to its misdescription are to be treated equally and will avoid the policy under all circumstances. On the contrary, the statute says only that unless one of these alternatives is present the policy cannot be declared void. Still, the Annotating Committee is in good company with its interpretation of Section I54. Courts and legal writers when interpreting statutory provisions in other states which form the model of Section 154 have never paid any attention to negative wording. On the contrary they have always read those statutes to

have been justified in refusing to insure-what shall we say then?" The trial court instructed the jury: "That the circumstances must have been such that the company would have been justified in refusing; that it could not relieve itself from liability merely by saying it would refuse. ...." (Italics added.) Counsel for the defendant insurance company excepted to this instruction and requested the court to charge that the company was its own judge as to what was justifiable in the matter of accepting or refusing a policy. The judgment was reversed on appeal on the theory that "it was entirely optional with the company whether or not it accepted this plaintiff's application and issued to him a policy....." Denler v. Continental Casualty Co., 213 App. Div. 30, 209 N.Y. Supp. 629 (1925). For a justification of the subjective test see'New York Insurance Code of $x 939$, 40 Col. L. Rev. 880 , 887 et seq. (I940); Patterson, op. cit. supra note 4 , at $\S 82$.

${ }^{20}$ E.g., Mass. Ann. Laws (I933) c. I75, § I86; Havighurst, op. cit. supra note I, at 403; the New York Insurance Code of 1939 has codified the subjective insurer test, N.Y. Ins. Law (McKinney, 1940) $\S \mathrm{r}_{49}(2)$ and (3). The argument in rebuttal of such an interpretation based on the wording of the statute is rather weak: the use of the present tense in the statute is by no means conclusive evidence that the two alternatives are only a tautological statement of the objective insurer test. (1922).

${ }^{21}$ Hancock v. Nat'l Council of the Knights and Ladies of Security, 303 IIl. 66, I35 N.E. 33

22 Havighurst, op. cit. supra note I, at 402 n. 65,403 . 
mean that either fraud or an increase of hazard is sufficient to avoid a policy. ${ }^{23}$

But is such an interpretation desirable? Is it not preferable to read the statute literally? This would mean that the presence of fraud or materiality is not necessarily sufficient but is only a minimum requirement. Section I 54 thus interpreted does not lay down a rigid rule but gives a very elastic one, enabling the courts to differentiate between various situations and to insist upon additional requirements should such insistence be fair and equitable. The question can only be answered on the basis of an examination of the two alternatives. They are a pair of very uneven requisites: the fraud alternative is a feature of insurance delinquency; the increase-ofhazard alternative is a matter of insurance economics.

II

Actual Intent to Deceive.-The fraudulent applicant intends to load the insurer with a contract he knows to be detrimental to the insurer. ${ }^{24}$ The

${ }_{23}$ E.g., Mack v. Pacific Life Ins. Co., I67 Minn. 53, 208 N.W. 4 I0 (I926), construing Minn. Stat. (Mason, 1937) § 3370; McDonough v. Metropolitan Life Ins. Co., 228 Mass. 450, II7 N.E. 836 (I917), interpreting Mass. Gen. Laws (I932) c. 175, $\$ 186$. The Kentucky Supreme Court for instance in interpreting a Kentucky statute had this to say: "If a representation is .... untrue and material, it taints the contract whether fraudulent or no't, and, if untrue and fraudulent, it taints the contract whether material or not." Nat'l Life \& Accident Ins. Co. v. Fisher, 2rr Ky. I2, 276 S.W. 981 (I925); Penn Mutual Life Ins. Co. v. Mechanics' Savings Bank, $7_{2}$ Fed. 413 (C.C.A. 6th r896). Contra: Johnson v. Nat'l Life Ins. Co., .x23 Minn. 453, I44 N.W. 218 (19r3); Franklin Fire Ins. Co. v. Shahan, 46 Ga. App. I8r, 167 S.E. I94 (1932). The Annotating Committee's point of view finds further support in the legislative history of the provision. An early draft of the provision contained, according to Havighurst, op. cit. supra note $\mathrm{x}$, at $402 \mathrm{n} .65$, the contribute-to-the-loss principle. A later draft required that breaches of warranties and misrepresentations be both fraudulent and material in order to defeat the policy. In the last draft "the common statutory provision most favorable to the companies was finally incorporated." Therefore, it is quite possible that the legislature also intended to favor the insurer by making fraud or materiality suffcient requirements for a denial of recovery. But did such an intention find its expression in the final wording of the statute?

24 Recent legal literature has not found fraud in the inception of the insurance contract worthy of the detailed treatment accorded to false warranties, misrepresentations, and concealment, not because the law on fraud has been settled beyond doubt by either common law or statute but rather because the practical importance of fraud as an independent ground for defeating recovery of a dishonest insured has diminished. Early insurance cases like Carter v. Boehm, 3 Burr. 1905 (K.B. 1766 ), inform us that the defense of fraud once was an important weapon in the hands of insurance underwriters who had miscalculated a risk because the insured had kept back circumstances in his knowledge relating to the risk. Out of these cases the common law developed the doctrine of fraudulent concealment and its use now is of considerable practical importance to fraud in the inception as a separate category. If the applicant had kept back relevant circumstances within his knowledge, the insurance underwriter was protected by the doctrine of concealment; had he made affirmative false statements the law of warranties or representations afforded ample protection to the underwriter. Park, Insurance ${ }_{774}$ ( $3 \mathrm{~d}$ ed. I796); The Evolution of the Doctrine of Concealment in Insurance Law and its Present Status, 9 Tulane L. Rev. 449 (I935). 
very nature of the insurance contract, which calls for indemnification out of a common fund in return for the payment of relatively small premiums, demands that an insurance contract be avoided in every case of fraud, thereby punishing and deterring fraudulent actions.

But what about so-called immaterial fraudulent misrepresentations? A majority of decisions seemingly have refused to regard an immaterial misrepresentation as fatal simply because it was made with actual intent to deceive. ${ }^{25}$ And these decisions have found the moral support of the legal literature which supplied the argument that "the purpose in allowing rescission is to protect the insurance company and its other policyholders against undesirable risks, not to punish the dishonest applicant whose dishonesty has caused no harm." ${ }^{96}$ To be sure, an insurance company should not be permitted to defeat recovery by proving that the insured has knowingly misstated a trivial matter. This situation can easily be taken care of by giving the applicant the benefit of the doubt. "If the facts present a case of misstatement on an immaterial point that was known to the applicant, the inference would ordinarily be that he had no. intention to deceive because he believed the matter to be immaterial." ${ }^{27}$ But without unduly stretching the imagination one can visualize extreme cases of actual intent to deceive which purely through chance do not materialize. Should, for instance, an insured who has fraudulently denied the storing of explosives, be entitled to recover simply because the explosives have become harmless by a fortuitous accident and without his knowledge?28 And should not the insurance company be permitted to terminate the relationship with such an insured, whose behavior has shown that he is quite capable of an insurance fraud? ${ }^{29}$ To take care of the wide variety of possible situations, the courts need sufficient leeway to enable them to deny recovery or to allow rescission at the initiative of the company in extreme cases of fraud even though the misstatement happens to be immaterial. This result can easily be reached if we read the statute literally and admit that under the statute fraud is only a minimum requirement. Any other interpretation of the statute does violence to its clear wording.

25 Patterson, op. cit. supra note 4 , at $\$ 84$.

26 Patterson, op. cit. supra note 4 , at 367 . This theory amounts to an application of the contribute-to-the-loss test; as to the latter see page 218 infra, note 33 .

27 Patterson, op. cit. supra note 4 , at 367.

${ }^{28}$ A precedent for this attitude may be found in Lynch and Jones v. Hamilton, 3 Taunt. 37 (C.P. I9I0), aff'd sub nom. Lynch v. Dunsford, I4 East 494 (K.B. I8II).

29 The problem is somewhat similar to that of the breach of a moral hazard warranty, note 40 infra. 
The theory that the insurance company is not protected under the fraud alternative if the misstatement is fraudulent but immaterial must necessarily affect the meaning of the materiality alternative. If, under the fraud alternative, fraud and materiality of a misstatement have to be present to prevent recovery, then, under the materiality alternative, materiality alone and unaccompanied by fraud can hardly be considered sufficient, for were materiality alone sufficient, the fraud alternative in the statute would be meaningless. But this latter result is inevitable under the prevailing theory unless we amputate with bold surgery the fraud alternative as surplusage altogether, or limit the materiality requirement to fraudulent misrepresentations, thereby preserving the venerable distinction between representations and warranties. ${ }^{30}$

Materiality.-It is almost an axiom of insurance law-in Illinois and elsewhere - that a misrepresentation or false warranty is material if the "true facts increase substantially the chances of the event insured against so as to cause a rejection of the application or the imposition of different conditions." Section I54 expresses the same idea..$^{3 x}$

This increase-of-hazard test of materiality is supposed to protect the insurance company in a wide variety of situations. On the one extreme is the case where the insurance company, had it been correctly informed by the insured about the risk, would have rejected the application because the true risk was technically uninsurable, thereby making the application unacceptable. On the other extreme is the case where the company, if correctly informed, would not have rejected the risk but rather would have accepted it, stipulating only for a slight increase in premiums. This observation confirms that the matter of materiality is not a question of insurance delinquency, as is the case of fraud, but a mere question of insurance economics to be settled by economic considerations.

So long as the event insured against has not happened, the insurance company must be given a right of rescission if it could justifiably have rejected the risk because of the real hazard-in other words, if the risk was unacceptable. This much is obvious. But how about the case where correct information would have led only to an increase in premiums, however slight? Is the same solution inevitable simply because the company

${ }^{30}$ The legal literature has always confined its criticism of the suggestion that a fraudulent misstatement irrespective of its materiality avoids a policy to fraudulent immaterial misrepresentations.

${ }^{35}$ The wording of' $\$ I_{54}$, "unless it.... materially affects either the acceptance of the risk or the hazard assumed by the company," makes it impossible to argue that the statute employs a subjective insurer standard. Since the "hazard assumed" alternative obviously describes an insurance-technical situation, "acceptance" can only mean "acceptability." 
cannot be regarded as bound to carry out a contract based on a miscalculation of the premiums due to a misdescription of the risk by the insured? The answer must be in the affirmative. If in the case of underinsurance the right of rescission should be denied, the insurer must be given the right to sue the insured for the premium difference. But that would mean burdening insurance companies with doubtful law suits, because the courts will not readily enforce a new contract at higher premiums. ${ }^{32}$

The economic aspect entirely changes after the event insured against has happened. Now it is possible to distinguish between the case where the risk was unacceptable and the case where it was only underinsured. To be sure, the insured cannot expect to receive full recovery since he has not paid the full premium on the basis of the real risk and paying the balance is out of the question. But to deny recovery altogether overstresses the potential risk increase created by the misrepresentation or breach of warranty.

It is in no way an absolute postulate of the policy of insurance law that misstatements of the risk (false warranties and misrepresentations) either will have no fatal consequences at all or, if material, will defeat recovery completely irrespective of whether the true risk was unacceptable or only underinsured. A few jurisdictions have felt in a vague way the defectiveness of this lack of discrimination in applying the increase-of-hazard test. But they have failed to see that it is not the increase-of-hazard test but only the sweeping application of an everything-or-nothing principle which causes this defect. To remedy the injustice these jurisdictions have replaced the increase-of-hazard test by the contribute-to-the-loss test, thereby going to the other extreme. ${ }^{33}$ They only ask whether or not the misdescribed factor actually contributed to the happening of the event insured against or actually increased the loss. Had the insured been fortunate in that the event insured against was not caused by the misdescribed risk factor he is entitled to recovery in full. In this situation the application of the contribute-to-the-loss principle gives the insured too much. He receives full compensation without having paid for the potential risk.

${ }^{32}$ This is born out by the experience of continental countries. Section $4 \mathrm{I}$ of the German Insurance Code which gives the insurance company the right to recover the premium difference has never become living law. Article 22 of the French Code gives the company the right to enforce the contract at an increased premium if accepted (!) by the insured. In this country an additional difficulty exists due to the unilateral nature of the insurance contract.

33 Only a few jurisdictions have adopted the,contribute-to-the-loss principle in its pure form. Most statutes belonging to this group have introduced it only in a hybrid form providing that the breach of warranty is fatal if it either did contribute to the loss or existed at the time of the loss. 
On the other hand, had the insured been unfortunate in that the misdescribed risk factor contributed in any way to the loss, he receives nothing, the degree of contribution being irrelevant. This shows that the contribute-to-the-loss principle if employed exclusively would apply the everything-or-nothing rule as in a lottery ${ }^{34}$ and does not afford a satisfactory solution at all.

Both the contribute-to-the-loss and the increase-of-hazard tests must. lead to unjust results so long as the everything-or-nothing principle is applied to situations where the insurance company would have only stipulated for higher premiums. They both give the insured in a rather mechanical way either too much, namely, more than he paid for, or nothing at all. This consideration leads to the notion of replacing the rigid everything-ornothing principle by the proportionate-reduction-of-recovery principle.

The proportionate-reduction-of-recovery principle is based on a rather simple idea. The insured, because of his misdescription of the actual risk, has paid only part of the premium he should have paid and consequently is entitled to receive only a proportionate share of the recovery. Despite its obvious appeal to our sense of fairness, the principle has been used in this country only in a few isolated instances.

It has been universally adopted (introduced by the insurance business itself) in the field of life insurance in the case where the applicant has misstated the basic factor of the risk, namely, his age. Since in life insurance the tariff premiums are calculated on the basis of the age of the insured, the application of the proportionate-reduction-of-recovery principle in cases of age misstatement is a matter of simple arithmetic: the amount of insurance is reduced to that sum which the premiums paid would have purchased at the true age of the insured. ${ }^{35}$ It is therefore not surprising that this regulation has been adopted all over the world.

Another illustration of the application of the proportionate-reductionof-recovery principle-in the field of property insurance and far removed from the matter of misstatements - is furnished by the so-called "average policy," sometimes agreed upon by the parties and sometimes provided for by statute. It obliges the insurer to make good such a proportion of the

34 The German Insurance Code does not furnish us with evidence in favor of the contributeto-the-loss test, as the American literature occasionally maintains. It mitigates the contributeto-the-loss test by combining it with an extreme exculpation principle, but only in favor of the insured. Whenever the contribute-to-the-loss test works to the detriment of the insured the latter may still recover in full should the court regard the misrepresentation as excusable. To avoid the everything-or-nothing principle the German courts frequently have gone to extremes in stressing the exculpation principle.

${ }^{35}$ N.X. Ins. Law (McKinney, I940) \& I55(r)(d); I A.I.R. 459 (I9I9); 14 A.L.R. 926 (192I). 
loss as the sum insured shall bear to the total value of the property at the time the event insured against occurs. Since the property insurers measure their risks by premiums calculated with regard to the sums insured, this clause again is an application of the proportionate-reduction-of-recovery principle.

An isolated attempt to introduce the principle into the law of fire insurance was not successful. ${ }^{36}$ The statute was a failure because it erroneously used the life insurance analogy and reduced the sum insured instead of the sum of recovery, thereby giving an undeserved advantage to the insured in many cases where the fire loss was only partial. ${ }^{37}$ Moreover, this statute maintains the contribute-to-the-loss test in terms of the everything-ornothing principle. Thus, if the fact of risk misrepresented has contributed in any way to the loss, the pro-rata principle is inapplicable.

The pro-rata principle is unquestionably the most equitable rule in cases of underinsurance due to the insured's misdescription of an acceptable risk. It takes into account the fact that the insurance company, if adequately informed, would not have rejected the application but properly would only have charged higher premiums, and at the same time it does not give the insured the unfair advantage of the full recovery he sometimes receives by operation of the contribute-to-the-loss principle. The insured can recover only on the basis of the premiums he actually has paid.

The question therefore arises whether there are reasons which prevent the general introduction of the proportionate-reduction-of-recovery principle. According to the literature on the subject the only serious obstacles are practical. The proportionate-reduction-of-recovery principle is said to be "unworkable in the absence of a reliable yardstick by which to measure the increase in premium." ${ }_{38}$ But could not this practical diffculty be taken care of to some extent at least by fictitious tariffs worked out "ad hoc" by insurance experts? It has to be conceded, however, that insofar as fictitious tariffs cannot be worked out, the increased risk has to be treated as unacceptable. To that extent, the pro-rata principle has to be replaced by the everything-or-nothing rule, and recovery must be denied.

${ }^{36} \mathrm{~A}$ New Hampshire statute provides: "A policy shall not be avoided by reason of any mistake or misrepresentation, unless it appears to have been intentionally and fraudulently made, or unless the difference between the property as it was represented and the property as it really existed contributed to the loss; but the sum insured by the policy shall be taken to be such fractional part of the sum mentioned therein as the premium paid by the insured is of the premium which he ought to have paid, not exceeding in any event the value of his interest in the property." N.H. Pub. Laws (1926) c. $276, \S 4$.

${ }^{37}$ Patterson, op. cit. supra note 4 , at $\$ 75$.

${ }^{38}$ Patterson, op. cit. supra note 4 , at 327 . 
But what about "moral hazard" misstatements? The increase of hazard caused by the misstatement is, of course, incalculable. ${ }^{39}$ The prorata principle, therefore, is inapplicable at the outset. The contribute-tothe-loss test, on the other hand, is also not available because the fact misdescribed is unable to contribute to the loss. The problem loses some of its difficulties, however, when we remind ourselves of the nature of the misrepresented facts in question. These facts are not factors of the risk itself but are mere indications of an abnormal additional risk: their presence increases the danger that the event insured against may be brought about by the fraud or carelessness of the insured. The double insurance of the same risk, for instance, may increase the danger of arson or the negligent treatment of the property insured-matters very difficult for the insurer to prove. So long as the event insured against has not occurred it is impossible to measure whether and to what degree such a misstatement will affect "the hazard assumed by the company." Therefore, the insurance company ought to be entitled to rescind the contract before loss whenever there is such a misstatement. But the situation might be different after the loss has occurred. Now the insured who is guilty of such a misstatement may show beyond any shadow of doubt that the loss was not the result of his fraud or carelessness. To use an illustration: there has been a misstatement as to former fires, but the insured can show that the fire insured against was the result of lightning or of the carelessness of a person he is not responsible for. Since in such a case the inference raised by the misstatement is not justified, the misstatement cannot be regarded as material at all (indirect application of the contribute-to-the-loss test). The burden of overcoming the inference being on the insured, it is unavoidable that recovery be denied if, for instance, the fire was a fire of "unknown origin," which is always suspicious (indirect application of the increase-ofhazard test). $4^{\circ}$ Such an indirect application of the increase-of-hazard

39 Patterson, op. cit. supra note 4, at 326.

${ }^{40}$ Another illustration is afforded by DePee v. Nat'l Life and Accident Ins. Co., I44 Kan. $75 \mathrm{r}, 754,62 \mathrm{P}$. (2d) 923,925 (1936) (a life insurance case). Here the insured who was killed in a gun-battle with public officials had falsely stated in his application that he had been a plasterer for fourteen years. In reality he had been in prison for robbery during seven of these fourteen years. The court in denying recovery under the Kansas contribute-to-the-loss statute said his "career of crime" (the fact misrepresented) "culminated in his violent death" and that therefore the misrepresented fact actually contributed to the event insured against. The court is here applying a fiction. In reality it is applying indirectly the increase-of-hazard test (unknown to the statute). This is confirmed by the court's statement: "A man who has adopted a career of .... robbery ..... is not as safe a risk as a man who follows the honorable and useful occupation of a plasterer." Consult by way of contrast Becker v. Kansas Castralty \& Surety Co., xo5 Kan. 99, I8I Pac. 549 ( $x 9$ x 9 ). Although the two cases use different rationalizations, it is significant that both deny recovery because the courts regarded the increased risk as unacceptable. 
test, however, presupposes that the insurer himself seriously considered the breach of the moral hazard warranty as risk increasing.

In determining this issue we should not lose sight of the fact that insurance underwriters have made excessive use of moral hazard warranties, such, for instance, as the "sole and unconditional ownership" clause often used as a club over the insured.4r Frequently it can be shown by the insured, on the basis of the constant practice (usage) of the insurance company involved, that it would have neither rejected the application nor charged higher premiums but would have waived the moral hazard provision. Thus the moral hazard cases are no insurmountable obstacle to the application of the pro-rata rule or principle. But this principle should be applied only within its proper domain-that of the underinsured but acceptable risk. This limitation has been overlooked by the French Insurance Code of I930, the most recent of the European insurance codes, which uses the pro-rata principle exclusively.42 Unacceptability of the risk, contribution to the loss, fraud, negligence however gross-all these factors are irrelevant. That such an exclusive application of the pro-rata rule produces unjust results may easily be demonstrated: a stock of goods has been insured against fire without disclosure that there are celluloid goods among them. Two situations might be contrasted. The insured, a skilled merchant, when asked whether the stock includes easily inflammable goods has answered in the negative. This answer amounts to gross negligence since he himself stored the celluloid goods which turned a small fire into a destructive conflagration. Or, the insured has not been asked about the presence of easily inflammable goods which have been stored by a clerk without the insured's knowledge, and the fire does not even reach these goods. In each case the insured recovers the same pro-rata share of his damages under the French statute. These examples make one wonder whether the pro-rata principle, even within its proper domain, ought not to be supplemented by the contribute-to-the-loss and the culpability ${ }^{43}$ principles cautiously used so that the pro-rata amount might be increased or decreased according to the merits of the individual case.

To sum up: the solution suggested here does not mean abolition of the increase-of-hazard test; it means only a limitation of the everything-or-

4I Goble, The Moral Hazard Clauses of the Standard Fire Insurance Policy, 37 Col. L. Rev. 4 IIO (1937).

42 Article 22 says apodictically with regard to non-fraudulent concealment or misstatement: "The recovery is to be reduced in proportion with the rate of premiums.the insured should have paid had he described the risk completely and exactly."

${ }^{43}$ The beginnings of a culpability doctrine may be found in the fraud rule and in the misrepresentation cases, note 18 supra. 
nothing rule. The latter rule is contrary to the nature and purpose of insurance and ought to be confined to cases of fraud and to those cases of increased hazard which make the risk unacceptable. Here neither the contribute-to-the-loss test nor the pro-rata principle can serve as a guide. The pro-rata principle has its proper domain where the risk is only underinsured. But as the French law shows, it has to be supplemented by the contribute-to-the-loss test and possibly even by the culpability principle. The moral hazard cases, as shown above, require a particular treatment, since the fact misstated is not a risk factor itself.

The Illinois courts are in the fortunate position of being able to use the various tests in the manner described, provided that the statute is read literally. Section I 54 thus read restricts only the application of the everything-or-nothing rule by prescribing minimum requirements without which a policy cannot be avoided. But beyond that there is still a legal vacuum open for the development of the common law along the lines indicated. That such a development is badly needed is illustrated by the fact that many legislatures, disappointed with the harshness of the everything-or-nothing principle, which might work both ways, have begun to experiment with other solutions. Only if we regard fraud and materiality as a minimum requirement can we afford to declare the common law distinction between (affirmative) warranties and representations as obsolete. The distinction has indeed outlived its usefulness under the interpretation of Section I 54 presented here. If, on the other hand, the presence of either fraud or materiality should be regarded as sufficient to defeat recovery irrespective of whether the risk was unacceptable or only underinsured, then the distinction has to be preserved in the interest of the insured, clumsy weapon though it be.

The problem of limiting the everything-or-nothing principle in the field of misrepresentations and false warranties has a larger aspect. It is part of the general problem of how to divide fairly the damage caused by technically defective conduct of the honest insured, e.g., breach of a continuous warranty, failure to prevent the extension of the loss, failure or delay to give notice, etc. In all these cases the proportionate-reduction-ofrecovery principle, enlarged into a general reduction-of-recovery principle, should find application. 